\title{
Synthesis, Crystal Structure and Thermal Behaviour of a New Three- dimensional Hybrid Fluoride Framework with Mixed Valence: $\left(\mathrm{Fe}^{2+} / \mathrm{Fe}^{3+}\right)$ \\ Mouna Smida ${ }^{1,2^{*}}$, Jérôme Lhoste ${ }^{1}$, Mohamed Dammak ${ }^{2}$, Annie Hémon-Ribaud ${ }^{1}$, Marc Leblan ${ }^{1}$, and Vincent Maisonneuve ${ }^{1}$ \\ ${ }^{1}$ Faculté des Sciences et Techniques, Université du Maine, Avenue Olivier Messiaen, France \\ ${ }^{2}$ Laboratoire de Chimie Inorganique, Faculté des Sciences de Sfax, Université de Sfax, Tunisia
}

\begin{abstract}
Crystal structure of metal-organic frameworks (MOF's) compound $[\mathrm{Hdma}] \cdot\left(\mathrm{Fe}^{2+} \mathrm{Fe}^{3+} \mathrm{F}_{6}(\mathrm{Hamtaz})_{2}\right)$ was hydrothermally synthesized, eventually assisted via classical heating (Acid Digestion Autoclave). Crystalline structure determination is formed from single crystal $X$-ray diffraction data. The unit cell is orthorhombic space group Imma, with cell parameters $a=15.9520(14) \AA, b=9.4548(7) \AA, c=9.7056(8) \AA, V=1463.8(2) \AA^{3}$ and $Z=4$. The structure $[\mathrm{Hdma}] \cdot\left(\mathrm{Fe}^{2+} \mathrm{Fe}^{3+} \mathrm{F}_{6}(\mathrm{Hamtaz})_{2}\right)$ exhibits a three-dimensional inorganic network resulting from the association of $\mathrm{Fe}^{\mathrm{I}} \mathrm{Fe} \mathrm{e}^{\mathrm{II}} \mathrm{F}_{6} \mathrm{~N}_{4}$ planes with Hamtaz molecules in the [010] direction, as well as uncoordinated dimethylammonium cations [Hdma] which are formed by the hydrolysis of DMF solvent. The thermal analysis (TG) of the title compound shows that the decomposition undergoes two steps between $200^{\circ} \mathrm{C}$ and $600^{\circ} \mathrm{C}$ and the total experimental mass loss $63.03 \%$ assuming that the hematite $\mathrm{Fe}_{2} \mathrm{O}_{3}$, is the final product of the decomposition.
\end{abstract}

Keywords: Hydrothermal synthesis; X-ray diffraction; Metal-organic frameworks; TG

\section{Introduction}

The synthesis of compounds containing more than one ligand using hydrothermal methods is much more difficult to control, and experimental synthesis conditions play a fundamental role. The formation of hybrid compounds is strongly determined by several factors, such as the molar ratio of reagents, $\mathrm{pH}$, reaction time, solvent, reaction temperature [1,2]. The hydrothermal synthesis of crystalline inorganic-organic hybrid compounds leads to two types of hybrid networks, according to the nature of bonding interactions [3]. In class I hybrids, the organic and inorganic parts are interlinked by weak interactions (van der Waals or hydrogen bonds) that contribute to the $3 \mathrm{D}$ structural stability. Whereas in the Class II hybrids, the metal atoms are strongly linked by covalent or iono-covalent bonds with the organic parts, to form metal-organic frameworks (MOF's). However, very few MOF's built up from fluorinated inorganic frameworks have been reported in the literature [4]. The interest for hybrid fluorinated materials is associated to the application in various domains ranging from gas storage (especially hydrogen) [5], catalysis [6], ion-exchange [7], magnetism [8], luminescence [9], biomedicine [10] etc. More recently, several crystalline forms have been proposed as components for secondary batteries, used as anode or cathode in rechargeable lithium batteries [11].

At the parallel, few hybrid fluoroferrate are listed. Most often, the metal fluoride species, which result from the condensation of FeA $B_{y}$ units $(A, B=N, O, F)$, are isolated polyanions or cluster such as $\mathrm{FeF}_{6}, \mathrm{FeF}_{5}\left(\mathrm{H}_{2} \mathrm{O}\right), \mathrm{FeF}_{2}\left(\mathrm{H}_{2} \mathrm{O}\right), \mathrm{FeF}_{4} \mathrm{~N}_{2}$ [12-21]. In fact, the research of inorganic $1 \mathrm{D}, 2 \mathrm{D}$ and $3 \mathrm{D}$ network structure is successful for class I and class II of hybrid fluoroferrate with triazole [22]. In this study, we have paid a great deal of attention to the hybrid iron fluoride compound as the object of our investigation. The aim of the present work is to study the structure determination and the thermal analysis of the second new three-dimensional network fluoroferrate with mixed valence $\mathrm{Fe}^{2+} / \mathrm{Fe}^{3+}$. We report here the results obtained by $\mathrm{X}$-ray single-crystal diffraction and differential thermogravimetric analysis (TG).

\section{Experimental Section}

\section{Synthesis of $[\mathrm{Hdma}] \cdot\left(\mathrm{Fe}^{2+} \mathrm{Fe}^{3+} \mathrm{F}_{6}(\mathrm{Hamtaz})_{2}\right)$}

All reagents and solvents are commercially available and were used as received without further purification. The starting chemicals were $\mathrm{FeF}_{2}$ and $\mathrm{FeF}_{3}(\geq 99.9 \%$, Alfa Aesar), hydrofluoric acid solution $4 \%$ (prepared from 40\% HF, Riedel De Haen), 3-amino-1,2,4-triazole (Hamtaz) (99\%, Alfa Aesar) and dimethylformamide (DMF) $(99.8 \%$, Sigma Aldrich). The $\mathrm{FeF}_{2}-\mathrm{FeF}_{3}-3$-amino-1,2,4-triazole- $\mathrm{HF}_{\text {aq. }}-\mathrm{DMF}$ system was investigated and established for a constant concentration $\left[\mathrm{Fe}^{\mathrm{II}}\right]+\left[\mathrm{Fe}^{\mathrm{III}}\right]=0.15$ mol. $\mathrm{L}^{-1}$ and a ratio $\left[\mathrm{Fe}^{\mathrm{II}}\right] /\left[\mathrm{Fe}^{\mathrm{III}}\right]=1$ under solvothermale condition at $120^{\circ} \mathrm{C}$ under autogenously pressure $(25 \mathrm{ml}$ Parr Autoclave) for 72 hour. The solid product was washed with DMF and dried at room temperature.

\section{X-ray crystallography}

Single-crystal X-ray diffraction data was collected at room temperature on an APEX II Quazar diffractometer (4-circle Kappa goniometer, $\mathrm{I} \mu \mathrm{S}$ microfocus source $\left(\mathrm{M}_{\mathrm{o}}, \mathrm{K}_{\alpha}\right)$, CCD detector). The structure was solved by direct methods which give the position of most of the atoms (iron, fluorine, nitrogen and carbon) developed by successive fourier maps and subsequent refinements using SHELXS-86 and SHELXL-97 [23-25] programs, where these last were included in WINGX package [26]. Non-hydrogen atoms were refined with anisotropic displacement parameters. Hydrogen atoms bonded to carbon and nitrogen were placed in geometrically idealized positions and included as riding atoms. The structure graphics were created by the DIAMOND program [27]. Crystal data and structure refinement details for the title compound are summarized in Table 1. The final positions and equivalent isotropic thermal parameters for the new compound are shown in Tables 2 and 3, while the selected bond lengths in $[\mathrm{Hdma}] \cdot\left(\mathrm{Fe}^{2+} \mathrm{Fe}^{3+} \mathrm{F}_{6}(\mathrm{Hamtaz})_{2}\right)$ is listed in Table 4. The Table

*Corresponding author: Mouna Smida, Faculté des Sciences et Techniques, Université du Maine, Avenue Olivier Messiaen, France, Tel: +0021695231854; E-mail:mouna.smida@yahoo.fr

\section{Received June 05, 2017; Accepted June 15, 2017; Published June 20, 2017}

Citation: Smida M, Lhoste J, Dammak M, Ribaud AH, Leblan M, et al. (2017) Synthesis, Crystal Structure and Thermal Behaviour of a New Three-dimensional Hybrid Fluoride Framework with Mixed Valence: $\left(\mathrm{Fe}^{2+} / \mathrm{Fe}^{3+}\right)$. Chem Sci J 8: 161 doi: 10.4172/2150-3494.1000161

Copyright: ( 2017 Smida M, et al. This is an open-access article distributed unde the terms of the Creative Commons Attribution License, which permits unrestricted use, distribution, and reproduction in any medium, provided the original author and source are credited. 
5 listed the hydrogen bond distances ( $\AA$ ) of the new three material $[\mathrm{Hdma}] \cdot\left(\mathrm{Fe}^{2+} \mathrm{Fe}^{3+} \mathrm{F}_{6}(\mathrm{Hamtaz})_{2}\right)$. Finally, a selected bond angles are given in Table 6 .

\section{Thermal analysis}

Thermogravimetric experiments was reported for the new threedimensional fluoroferrate with a thermoanalyzer NETZSCH STA 449 $\mathrm{F} 3$ under humid air atmosphere and a heating rate of $5^{\circ} \mathrm{C} \cdot \mathrm{min}^{-1}$ from $25^{\circ} \mathrm{C}$ up to $895^{\circ} \mathrm{C}$.

\section{Results and Discussion}

\section{Structure description of $[\mathrm{Hdma}] \cdot\left(\mathrm{Fe}^{2+} \mathrm{Fe}^{3+} \mathrm{F}_{6}(\mathrm{Hamtaz})_{2}\right)$}

Single crystal X-ray diffraction analyses, at room temperature indicate that the $3 \mathrm{D}[\mathrm{Hdma}] \cdot\left(\mathrm{Fe}^{2+} \mathrm{Fe}^{3+} \mathrm{F}_{6}(\mathrm{Hamtaz})_{2}\right)$ compounds crystallizes in the orthorhombic space group Imma. Final refinements of anisotropic displacement parameters (ADP) and secondary extinction converged to $\mathrm{R}=0.046 \%$ and $\mathrm{W}_{\mathrm{R}}=0.126 \%$ ( 1219 independent reflections and 91 parameters). Two iron atoms are located on special $4 \mathrm{c}$ position $(\mathrm{Fe}(2))$ and general $4 \mathrm{e}$ position $(\mathrm{Fe}(1))$. Successive Fourier maps and refinements allowed locating fluorine, nitrogen atoms and organic moieties. $\mathrm{F}(2), \mathrm{F}(3)$ and $\mathrm{F}(4)$ atomic positions were statistically occupied with 0.75 site occupancy whereas for $\mathrm{F}(5)$ and $\mathrm{F}(6)$ atomic positions occupied with 0.25 site occupancy, moreover, one nitrogen atom and one carbonate atom were disordered on $\mathrm{N}(1) / \mathrm{C}(1)$ sites for electronic neutrality and from distances and environment considerations. Furthemore, $\mathrm{N}(1)$ and $\mathrm{C}(1)$ atoms statistically distributed on a general position, as shown in Table 2 . The fluoride atoms are randomly distributed over several positions. In fact, the occupation of the fluoride sites was done freely at their positions, which corresponds to six fluorine atoms per unit formula. Hydrogen atoms

\begin{tabular}{|c|c|}
\hline Crystal data Formula & $\mathrm{C}_{6} \mathrm{H}_{8} \mathrm{~F}_{6} \mathrm{Fe}_{2} \mathrm{~N}_{9}$ \\
\hline Crystal System & Orthorhombic \\
\hline Space Group & Imma \\
\hline $\mathrm{a}(\AA)$ & $15.9520(14)$ \\
\hline$b(\AA)$ & $9.4548(7)$ \\
\hline$c(\AA)$ & $9.7056(8)$ \\
\hline$\alpha\left(\left(^{\circ}\right)=\beta\left(^{\circ}\right)=y\left(\left(^{\circ}\right)\right.\right.$ & 90 \\
\hline $\mathrm{V}\left(\AA^{3}\right)$ & $1463.8(2)$ \\
\hline z & 4 \\
\hline$F(000)$ & 852 \\
\hline Formula weight $\left(\mathrm{g} \cdot \mathrm{mol}^{-1}\right)$ & 431.91 \\
\hline Dimensions (mm) & $0.15 \times 0.12 \times 0.08$ \\
\hline$\mu\left(\mathrm{mm}^{-1}\right)$ & 2.06 \\
\hline$\rho$ calculated $\left(\mathrm{g} \cdot \mathrm{cm}^{-3}\right)$ & 1.96 \\
\hline Temperature (K) & 296 \\
\hline Radiation, $(\AA)$ & Mo Ka, 0.71073 \\
\hline 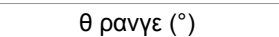 & $2.46 / 30.50$ \\
\hline \multirow[t]{3}{*}{ Limiting indices } & $-22 \leq h \leq 22$ \\
\hline & $-10 \leq k \leq 13$ \\
\hline & $-13 \leq 1 \leq 13$ \\
\hline Collected reflections & 7885 \\
\hline Reflections Unique & 1219 \\
\hline Parameter refined & 91 \\
\hline Goodness of fit $\left(\mathrm{F}^{2}\right)$ & 1.08 \\
\hline $\mathrm{R}_{1}[|2|]$ & 0.0465 \\
\hline $\mathrm{WR}_{2}$ & 0.1265 \\
\hline$\rho \min / \max \left(e \AA^{-3}\right)$ & $-0.815 / 1.176$ \\
\hline
\end{tabular}

Table 1: Crystallographic data of $[\mathrm{Hdma}] \cdot\left(\mathrm{Fe}^{2+} \mathrm{Fe}^{3+} \mathrm{F}_{6}(\mathrm{Hamtaz})_{2}\right)$ at room temperature.

\begin{tabular}{|c|c|c|c|c|c|}
\hline Atoms & $\mathbf{X}$ & $\mathbf{Y}$ & $\mathbf{Z}$ & $\mathbf{U}_{\text {iso }}{ }^{*} \mathbf{U}_{\text {eq }}$ & Occ. $(<1)$ \\
\hline $\mathbf{F e 1}$ & 0 & 0.25 & $0.28355(8)$ & $0.0187(2)$ & \\
\hline Fe2 & 0.25 & 0.25 & 0.25 & $0.0178(2)$ & \\
\hline F1 & $0.12504(12)$ & 0.25 & $0.2837(3)$ & $0.0282(6)$ & \\
\hline F2 & 0 & 0.25 & $0.0891(6)$ & $0.096(4)$ & 0.75 \\
\hline F3 & 0 & $\begin{array}{c}0.0530 \\
(5)\end{array}$ & $0.2774(10)$ & $0.085(2)$ & 0.75 \\
\hline F4 & 0 & 0.25 & $0.4747(6)$ & $0.084(3)$ & 0.75 \\
\hline F5 & 0 & $0.383(2)$ & $0.141(2)$ & $0.083(7)$ & 0.25 \\
\hline F6 & 0 & $0.108(3)$ & $0.416(3)$ & $0.119(11)$ & 0.25 \\
\hline N1/C1 & $0.34857(19)$ & $\begin{array}{c}-0.0479 \\
(5)\end{array}$ & $0.5493(4)$ & $0.0593(13)$ & $0.50 / 0.50$ \\
\hline H1 & $0.3930(16)$ & $\begin{array}{c}-0.082 \\
(5)\end{array}$ & $0.575(5)$ & $0.071^{*}$ & \\
\hline N2 & $0.27094(15)$ & $\begin{array}{c}-0.0816 \\
(3)\end{array}$ & $0.5858(2)$ & $0.0262(5)$ & \\
\hline N3 & $0.1428(3)$ & 0 & 0.5 & $0.168(6)$ & \\
\hline H3A & 0.1158 & 0.0536 & 0.4437 & $0.202^{*}$ & 0.5 \\
\hline H3B & 0.1158 & -0.0536 & 0.5563 & $0.202^{*}$ & 0.5 \\
\hline C2 & $0.2257(3)$ & 0 & 0.5 & $0.0404(12)$ & \\
\hline C3 & 0.5 & 0.25 & $0.7062(15)$ & $0.100(5)$ & \\
\hline C4 & $0.3483(16)$ & 0.25 & $0.771(2)$ & $0.084(5)$ & 0.5 \\
\hline N4 & $0.4357(12)$ & $\begin{array}{c}0.2939 \\
(16)\end{array}$ & $0.8013(17)$ & $0.069(5)$ & 0.25 \\
\hline
\end{tabular}

Table 2: Fractional atomic coordinates and equivalent isotropic displacement parameters $\left(\mathrm{U}_{\text {iso }}\right.$ for $\mathrm{H}$ atoms $)$ for [ $\left.\mathrm{Hdma}\right] \cdot\left(\mathrm{Fe}_{2}+\mathrm{Fe}_{3}+\mathrm{F}_{6}(\mathrm{Hamtaz})_{2}\right)$ material.

of Hamtaz neutral were placed with HFIX options ( 43 for $\mathrm{CH}, \mathrm{NH}$, and 93 for $\mathrm{NH}_{2}$ ). The structure for the title compound is built up from $\mathrm{Fe}_{2} \mathrm{~F}_{6}$ (Hamtaz) ${ }_{2}$ planes connected by Hamtaz ligands which separated by dimethylammonuim cations coming from the hydrolysis of DMF solvent, resulting a second three-dimensional hybrid fluoride with 3D inorganic connectivity (Figure 1a and $1 \mathrm{~b}$ ). It is crystallizes in the same system orthorhombic with identical Centro symmetric space group Imma, accompanying different cell parameters, comparable to the first $3 \mathrm{D} \mathrm{Fe}_{2} \mathrm{~F}_{5}(\mathrm{Htaz})[22]$.

From the Figure 1, we note that the arrangement of the various octahedral and organic molecules forms a tunnels with square cross section where the $[\mathrm{Hdma}]$ cations are located, the side of the square is equal to $6.774 \AA$. Thus this structure of the new material involve anionic $\mathrm{Fe}_{2} \mathrm{~F}_{6} \mathrm{~N}_{4}$ infinite trans-chains along (100) direction. The average $\langle\mathrm{C}-\mathrm{C}\rangle$ and $\langle\mathrm{N}-\mathrm{C}\rangle$ distances of Hamtaz molecules are varied between $1.32 \AA$ and $1.42 \AA$, in fact there are the same geometry than that found in the succession of guanazolium fluoroaluminates $[28,29]$. Dimethylammonium cations are strongly disordered, in fact two different positions for $\mathrm{N}(4)$ and $\mathrm{C}(4)$ atoms were located with refined occupation being close to one quarter and one half, respectively, form one member of [Hdma] entity per unit formula. The formulation $[\mathrm{Hdma}] \cdot\left(\mathrm{Fe}_{2} \mathrm{~F}_{6}(\mathrm{Hamtaz})_{2}\right)$ was then obtained. A projection on the $\mathrm{cb}$ plane (Figure 1) shows that this structure contains two type of octahedral forming a $\mathrm{Fe}^{\mathrm{III}} \mathrm{Fe}^{\mathrm{II}} \mathrm{F}_{6} \mathrm{~N}_{4}$ trimers. As a consequence, the structure presents two oxidation states for iron atoms. Every anionic $\mathrm{Fe}^{\mathrm{III}}{ }_{2} \mathrm{Fe}^{\mathrm{II}} \mathrm{F}_{6} \mathrm{~N}_{4}$ trimer is connected to four neutral Hamtaz molecules by four symmetry nitrogen atoms $\mathrm{N}(2)$ along the (11̄0) and (110) directions. However, two types of coordination of the iron cations are observed in the new 3D fluoroferrate: (Figure 2 left) a distorted $\mathrm{Fe}(1) \mathrm{F}_{6}$ octahedral in which $\mathrm{Fe}(1)$ is surrounded by ten fluorine atoms while the $\mathrm{Fe}(1)-\mathrm{F}$ bond length varied between 1.855(6) and 1.995(2) $\AA$, and in the Figure 2 right of $\mathrm{Fe}(2) \mathrm{F}_{2} \mathrm{~N}_{4}$ octahedral, in which $\mathrm{Fe}(2)$ is coordinated to two fluorine atoms, and four nitrogen atoms from four neutral Hamtaz molecules, where the $\mathrm{Fe}(2)-\mathrm{F}$ and $\mathrm{Fe}(2)-\mathrm{N}$ distances equal to 2.020(2) $\AA$ and 2.278(2) $\AA$, respectively. In fact, it must be noted that the oxidation 
Citation: Smida M, Lhoste J, Dammak M, Ribaud AH, Leblan M, et al. (2017) Synthesis, Crystal Structure and Thermal Behaviour of a New Threedimensional Hybrid Fluoride Framework with Mixed Valence: $\left(\mathrm{Fe}^{2+} / \mathrm{Fe}^{3+}\right)$. Chem Sci J 8: 161. doi: 10.4172/2150-3494.1000161

\begin{tabular}{|c|c|c|c|c|c|c|}
\hline Atoms & $U^{11}$ & $\mathbf{U}^{22}$ & $\mathbf{U}^{33}$ & $U^{12}$ & $U^{13}$ & $\mathbf{U}^{23}$ \\
\hline Fe1 & $0.0107(3)$ & $0.0251(4)$ & $0.0203(4)$ & 0.000 & 0.000 & 0.000 \\
\hline $\mathrm{Fe} 2$ & $0.0108(3)$ & $0.0197(4)$ & $0.0229(4)$ & 0.000 & $0.0017(2)$ & 0.000 \\
\hline F1 & $0.0126(11)$ & $0.0373(15)$ & $0.0347(13)$ & 0.000 & $0.0024(8)$ & 0.000 \\
\hline F2 & $0.063(5)$ & $0.206(13)$ & $0.018(3)$ & 0.000 & 0.000 & 0.000 \\
\hline F3 & $0.041(3)$ & $0.024(2)$ & $0.191(8)$ & 0.000 & 0.000 & $-0.014(3)$ \\
\hline F4 & $0.035(3)$ & $0.192(11)$ & $0.024(3)$ & 0.000 & 0.000 & 0.000 \\
\hline N1 & $0.0187(13)$ & $0.090(3)$ & $0.069(2)$ & $0.0032(17)$ & $-0.0011(14)$ & $0.057(2)$ \\
\hline C1 & $0.0187(13)$ & $0.090(3)$ & $0.069(2)$ & $0.0032(17)$ & $-0.0011(14)$ & $0.057(2)$ \\
\hline N2 & $0.0237(11)$ & $0.0273(12)$ & $0.0277(11)$ & $0.0005(9)$ & $-0.0004(9)$ & $0.0090(9)$ \\
\hline N3 & $0.020(2)$ & $0.230(11)$ & $0.256(11)$ & 0.000 & 0.000 & $0.217(10)$ \\
\hline $\mathrm{C} 2$ & $0.0185(18)$ & $0.045(3)$ & $0.058(3)$ & 0.000 & 0.000 & $0.029(2)$ \\
\hline $\mathrm{C} 3$ & $0.132(14)$ & $0.089(10)$ & $0.078(9)$ & 0.000 & 0.000 & 0.000 \\
\hline $\mathrm{C} 4$ & $0.101(13)$ & $0.067(11)$ & $0.085(12)$ & 0.000 & $-0.020(10)$ & 0.000 \\
\hline N4 & 0.109 (14) & $0.044(8)$ & $0.055(9)$ & $-0.013(8)$ & $-0.012(9)$ & $0.000(6)$ \\
\hline F5 & $0.016(5)$ & $0.114(15)$ & $0.119(15)$ & 0.000 & 0.000 & $0.085(14)$ \\
\hline F6 & $0.036(8)$ & $0.18(2)$ & $0.15(2)$ & 0.000 & 0.000 & $0.14(2)$ \\
\hline
\end{tabular}

Table 3: Atomic displacement parameters of $[\mathrm{Hdma}] \cdot\left(\mathrm{Fe}^{2+} \mathrm{Fe}^{3+} \mathrm{F}_{6}(\mathrm{Hamtaz})_{2}\right)$ compound.

\begin{tabular}{|c|c|c|c|}
\hline $\begin{array}{c}\text { Selected bond } \\
\text { distances }\end{array}$ & $\begin{array}{c}\text { Distances bond } \\
\mathbf{( A )}\end{array}$ & $\begin{array}{c}\text { Selected bond } \\
\text { distances }\end{array}$ & $\begin{array}{c}\text { Distances bond } \\
(\mathbf{A})\end{array}$ \\
\hline Fe1-F4 & $1.855(6)$ & N1-N2 & $1.327(4)$ \\
\hline Fe1-F6 & $1.863(9)$ & N1-H1 & $0.8200(8)$ \\
\hline Fe1-F3 & $1.864(4)$ & N2-C2 & $1.345(3)$ \\
\hline Fe1-F5 & $1.871(8)$ & N3-C2 & $1.322(6)$ \\
\hline Fe1-F2 & $1.887(6)$ & N3-H3A & 0.86 \\
\hline Fe1-F1 & $1.995(2)$ & N3-H3B & 0.86 \\
\hline Fe2-F1 & $2.020(2)$ & C2-N2 & $1.345(3)$ \\
\hline Fe2-N2 & $2.278(2)$ & C3-N4 & $1.44(2)$ \\
\hline N1-C1 & $1.318(6)$ & C4-N4 & $1.48(3)$ \\
\hline N1-N1 & $1.318(6)$ & N4-N4 & $0.83(3)$ \\
\hline N1-H1 & $0.8200(8)$ & N1-N2 & $1.327(4)$ \\
\hline
\end{tabular}

Table 4 : Selected bond distances $(\AA)$ in 3D hybride fluoroferrate.

\begin{tabular}{|c|c|c|c|}
\hline Selected bond & Distances & Selected bond & Distances \\
\hline distances & $d(\mathrm{H} \cdots \mathrm{F})(\mathrm{A})$ & distances & $d(\mathrm{H} \cdots \mathrm{F})(\mathrm{A})$ \\
\hline$N(3)-H(3 A) \cdots F(6)^{i i}$ & $1.936(3)$ & $\mathrm{N}(3)-\mathrm{H}(3 \mathrm{~B}) \cdot \mathrm{F}(3)^{\mathrm{iii}}$ & $2.453(1)$ \\
\hline$N(3)-H(3 A) \cdots F(1)^{i}$ & $2.425(2)$ & $\mathrm{N}(3)-\mathrm{H}(3 \mathrm{~B}) \cdots \mathrm{F}(4)^{\mathrm{iii}}$ & $2.636(5)$ \\
\hline$N(3)-H(3 A) \cdots F(3)^{i \tilde{i}}$ & $2.453(1)$ & $N(1) / C(1)-H(1) \cdots F(2)$ iii & $2.335(6)$ \\
\hline$N(3)-H(3 A) \cdot F(6)^{i i i}$ & $2.757(0)$ & $N(1) / C(1)-H(1) \cdots F(5)^{v}$ & $1.852(9)$ \\
\hline $\mathrm{N}(3)-\mathrm{H}(3 \mathrm{~A}) \cdots \mathrm{F}(4)^{\mathrm{ii}}$ & $2.636(5)$ & $N(1) / C(1)-H(1) \cdots F(1)^{i v}$ & $2.590(1)$ \\
\hline $\mathrm{N}(3)-\mathrm{H}(3 \mathrm{~B}) \cdots \mathrm{F}(6) \mathfrak{i}$ & $2.757(0)$ & $N(1) / C(1)-H(1) \cdots F(3)^{v i}$ & $2.616(8)$ \\
\hline$N(3)-H(3 B) \cdot F(1)^{i i i}$ & $2.425(2)$ & & \\
\hline$N(3)-H(3 B) \cdot F(6)^{i i i}$ & $1.936(3)$ & & \\
\hline
\end{tabular}

Table 5: Hydrogen bond distances $(\AA)$ in $[\mathrm{Hdma}] \cdot\left(\mathrm{Fe}^{2+} \mathrm{Fe}^{3+} \mathrm{F}_{6}(\mathrm{Hamtaz})_{2}\right)$ complex Symmetry codes : (i) $x, 0.5-y, z$; (ii) $-x, y, z$; (iii) $x,-y, 1-z$; (iv) $0.5-x, 0.5+y,-0.5+z$; (v) $0.5-x,-0.5+y, 0.5+z ;(v i) 0.5-x,-y,-0.5+z$.

state for $\mathrm{Fe}(1)$ and $\mathrm{Fe}(2)$ atoms are $+\mathrm{III}$ and $+\mathrm{II}$, respectively, and the ligands established between $\mathrm{Fe}(2)$ and nitrogen atoms of Hamtaz molecules lead to deduce that this new fluoroferrate with mixed valence is a Class II hybrid (Figure 3).

A similar Fe-F distances for two oxidation state of iron, are found in the series of hybrid fluoroferrates with triazoles, with bis-(2ethylamino)amine [dien] and with tris-(2-ethylamino)amine [tren], where the fluorine ions are involved in H-bonding [17-18,22].

Among the ten fluorine ions (Figure 3), F(1) is coordinated with two iron atoms $\mathrm{Fe}(1)$ and $\mathrm{Fe}(2)$. Obviously, all fluorine atoms except $\mathrm{F}(1)$ are linked to only one $\mathrm{Fe}(1)$ atom in the centre of $\mathrm{FeF}_{6}$ anion. Moreover, the octahedral units of the title compound are strongly distorted with short
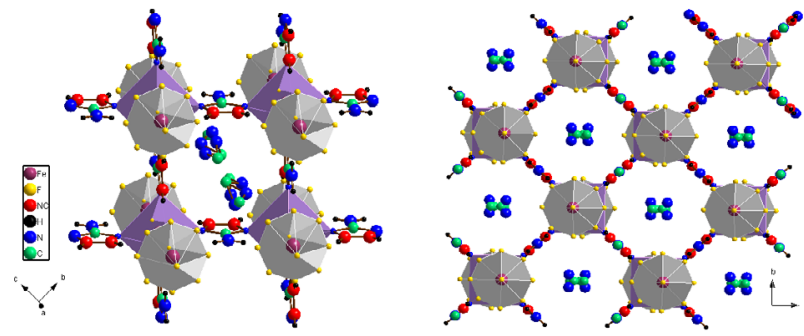

Figure 1: Projection of the 3D [Hdma] $\cdot\left(\mathrm{Fe}^{2+} \mathrm{Fe}^{3+} \mathrm{F}_{6}(\mathrm{Hamtaz})_{2}\right)$ structure (left), and view along the [100] direction of the structure (right).
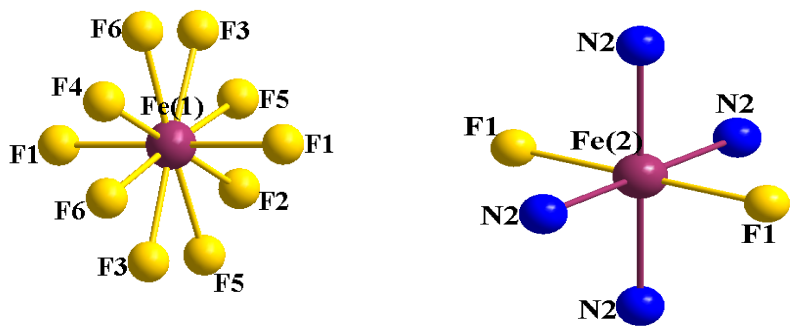

Figure 2: Representation of $\mathrm{FeF}_{2} \mathrm{~N}_{4}$ octahedra and disordered $\mathrm{FeF}_{6}$ in $[\mathrm{Hdma}] \cdot\left(\mathrm{Fe}^{2+} \mathrm{Fe}^{3+} \mathrm{F}_{6}(\mathrm{Hamtaz})_{2}\right)$ compound.

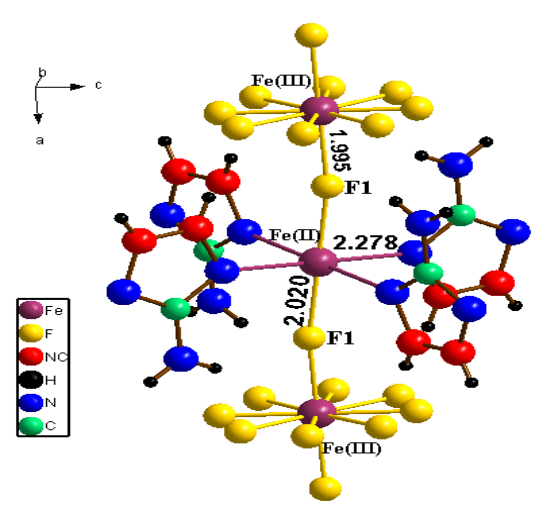

Figure 3: View along the $b$ axis, showing the build of fluoroferrate with Hamtaz molecules. 
distances between $\mathrm{Fe}$ atoms and terminal fluorine atoms $\mathrm{F}(2), \mathrm{F}(3)$, $\mathrm{F}(4), \mathrm{F}(5)$ and $\mathrm{F}(6)$, medium distances between $\mathrm{Fe}$ atoms and bridging $\mathrm{F}(1)$ atoms, and long distances between $\mathrm{Fe}$ atoms and nitrogen atoms $\mathrm{N}(2)$. The $\mathrm{Fe}^{\mathrm{III}}-\mathrm{F}(1)-\mathrm{Fe}^{\mathrm{II}}$ angle is equal to $170.64^{\circ}$, whereas the both $\mathrm{F}(1)-\mathrm{Fe}^{\mathrm{III}}-\mathrm{F}(1)$ and $\mathrm{F}(1)-\mathrm{Fe}^{\mathrm{II}}-\mathrm{F}(1)$ angle values counterpart to $179.94^{\circ}$ and $180^{\circ}$, respectively (Table 6).

In the new hybrid framworks structure of $[\mathrm{Hdma}] \cdot\left(\mathrm{Fe}^{2+} \mathrm{Fe}^{3+} \mathrm{F}_{6}(\mathrm{Hamtaz})_{2}\right)$ the coordination of $\mathrm{M}^{\mathrm{II}}$ and $\mathrm{M}^{\mathrm{III}}$ metals is identical with that found in the series of hybrid fluoroferrates with triazoles: for $\mathrm{FeF}_{6}$ clusters in [Hdma] $\cdot\left(\mathrm{Fe}_{2}-\left(\mathrm{H}_{2} \mathrm{O}\right)_{4} \mathrm{~F}_{6}\right)$, [Hdma] $\left(\mathrm{Fe}_{2}-\right.$ $\left.\left(\mathrm{H}_{2} \mathrm{O}\right)_{4} \mathrm{~F}_{6}\right) \cdot 0.5 \mathrm{H}_{2} \mathrm{O}$ and $\mathrm{Fe}_{2} \mathrm{~F}_{5}(\mathrm{Htaz})$, and for $\mathrm{FeF}_{2} \mathrm{~N}_{4}$ clusters in [Hdma] $\cdot\left(\mathrm{Fe}_{2} \mathrm{~F}_{5}\left(\mathrm{H}_{2} \mathrm{O}\right)(\mathrm{Htaz})(\mathrm{taz})\right)$ and [Hdma] $\cdot\left(\mathrm{Fe}_{2} \mathrm{~F}_{5}(\mathrm{taz})_{2}\right)[22]$.

From Figure 4, we observed the hydrogen bonds exist between fluorine anions of distorted $\mathrm{Fe}(1) \mathrm{F}_{6}$ octahedra, the primary and secondary amine group and $\mathrm{C}-\mathrm{H}$ groups of eight Hamtaz molecules. The $\mathrm{H}(1)$ hydrogen atom of the secondary amine group or the $\mathrm{C}-\mathrm{H}$ group, is oriented towards four fluorine anions of $\mathrm{FeF}_{6}$ octahedron, such as the $\mathrm{H}(1)-\mathrm{F}(1)$ length is $2.59 \AA$ and the $\mathrm{N}(1) / \mathrm{C}(1)-\mathrm{H}(1) \cdots \mathrm{F}(1)$ angle is $112^{\circ}$, are indicative of weak hydrogen bonds in a new three dimensional micro porous fluoride. Furthermore, the hydrogenbonding interactions in the structure contribute to the stability of the 3D network. The $\mathrm{N}-\mathrm{H} \cdots \mathrm{F}$ and $\mathrm{C}-\mathrm{H} \cdots \mathrm{F}$ distances are varied from 1.852(9) $\AA$ to 2.757(0) Å and close to the distances observed in fluoride metalates templated with tren (tris-(2-aminoethyl)amine) [12,13] (Table 5).

\section{Thermogravimetric analysis}

The TG thermal analysis in oxygen dynamic atmosphere of the title compound is given in Figure 5. During heating, it decomposes in different ways continuous at different temperature between $200^{\circ} \mathrm{C}$ and $600^{\circ} \mathrm{C}$ and it shows that the compound prepared is stable at room temperature. The weight loss is attributed to the decomposition of $[\mathrm{Hdma}] \cdot\left(\mathrm{Fe}^{2+} \mathrm{Fe}^{3+} \mathrm{F}_{6}(\mathrm{Hamtaz})_{2}\right)$ to give the amine fluoride and $\mathrm{HF}$ gas. The first stage between $100^{\circ} \mathrm{C}$ and $350^{\circ} \mathrm{C}$ approximately, probably due to the release of $1.25 \mathrm{~mol}$ of Hamtaz molecule and eventually, $6 \mathrm{~mol}$ of hydrofluoric acid (HF), while the experimental mass loss equal to $52.12 \%$. Moreover, the second step in the temperature range of $350^{\circ} \mathrm{C}$ and $550^{\circ} \mathrm{C}$, approximately, is attributed to the elimination of the rest of organic moieties that corresponds to $10.91 \%$ of the experimental mass loss. In fact, the loss of HF and decomposition of Hamtaz molecules and the creation of $\mathrm{FeF}_{2}$, make up a total experimental mass loss of $63.03 \%$. At high temperature, above $600^{\circ} \mathrm{C}$ the $\mathrm{Fe}_{2} \mathrm{O}_{3}$ hematite compound is product [21-23]. The total experimental mass loss value $63.03 \%$ is in good agreement with the theoretical mass loss $63.03 \%$ assuming that the hematite $\mathrm{Fe}_{2} \mathrm{O}_{3}$, is the final product of the oxidation.

\section{Conclusion}

New three-dimensional mixed valence fluoroferrate obtained from the reaction of $\mathrm{FeF}_{2}$ and $\mathrm{FeF}_{3}$ with 3-amino-1,2,4-triazole and aqueous HF in DMF solvent. The structural properties and the thermal behavior for $[\mathrm{Hdma}] \cdot\left(\mathrm{Fe}^{2+} \mathrm{Fe}^{3+} \mathrm{F}_{6}(\mathrm{Hamtaz})_{2}\right)$ are reported. The structure exhibit $\mathrm{M}^{\mathrm{II}} \mathrm{N}_{4} \mathrm{~F}_{2}$ and $\mathrm{M}^{\mathrm{III}} \mathrm{F}_{6}$ octahedral units in which nitrogen atoms come from neutral amines, forming the infinitie layers of $\mathrm{Fe}_{2} \mathrm{~F}_{6}(\mathrm{Hamtaz})_{2}$, where the $[\mathrm{Hdma}]$ cations are located in the cavities. This structure while being regarded the notation of Cheetham [30] leading to 3-D dimensionality with respect to both organic connectivity between metal centers $\left(\mathrm{O}^{\mathrm{n}}\right)$ and extended inorganic connectivity $\left(\mathrm{I}^{\mathrm{n}}\right)$ therefore the notation of Cheetham is $\mathrm{I}^{1} \mathrm{O}^{2}$ ( $\mathrm{I}=$ inorganic and $\mathrm{O}=$ organic), note that the sum of

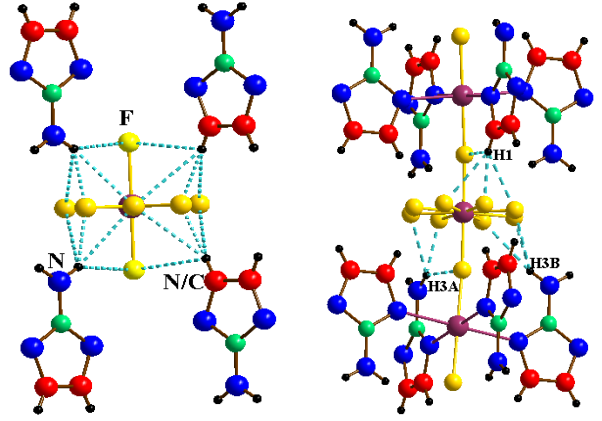

Figure 4: Network of hydrogen bonds between amine cations and fluoride ions in the $[\mathrm{Hdma}] \cdot\left(\mathrm{Fe}^{2+} \mathrm{Fe}^{3+} \mathrm{F}_{6}(\mathrm{Hamtaz})_{2}\right)$ structure.

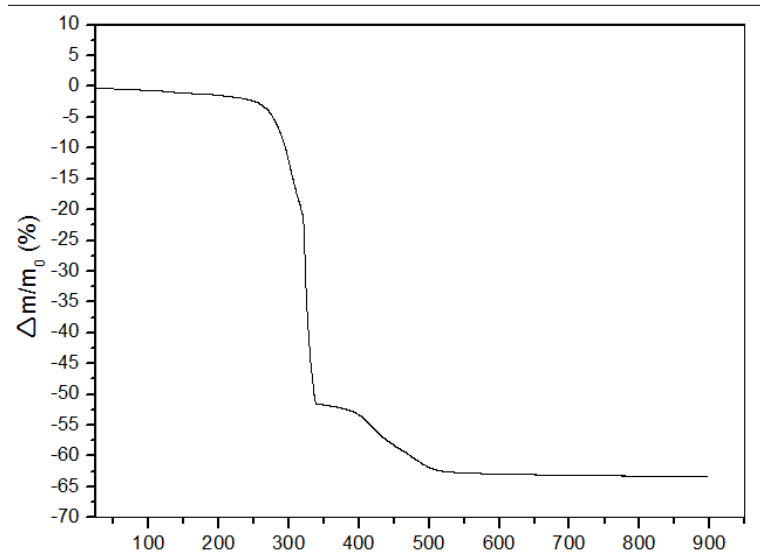

Figure 5: TG heating curve of $[\mathrm{Hdma}] \cdot\left(\mathrm{Fe}^{2+} \mathrm{Fe}^{3+} \mathrm{F}_{6}(\mathrm{Hamtaz})_{2}\right)$ material.

\begin{tabular}{|c|c|c|c|}
\hline Selected bond angles & Degree $\left({ }^{\circ}\right)$ & Selected bond angles & Degree $\left({ }^{\circ}\right)$ \\
\hline$F(1)-F e(1)-F(1)^{6}$ & $179.94(16)$ & $F(3)-F e(1)-F(5)$ & $130.5(11)$ \\
\hline$F(2)-F e(1)-F(1)$ & $90.03(8)$ & $F(4)-F e(1)-F(5)$ & $137.7(9)$ \\
\hline$F(3)-F e(1)-F(1)$ & $90.00(3)$ & $F(6)-F e(1)-F(5)$ & $176.1(14)$ \\
\hline$F(4)-F e(1)-F(1)$ & $89.97(8)$ & $\mathrm{F}(1)-\mathrm{Fe}(2)-\mathrm{N}(2)^{4}$ & $91.81(8)$ \\
\hline$F(5)-F e(1)-F(1)$ & $90.02(6)$ & $\mathrm{N}(2)^{2}-\mathrm{Fe}(2)-\mathrm{N}(2)^{4}$ & $88.69(13)$ \\
\hline$F(6)-F e(1)-F(1)$ & $89.98(6)$ & $\mathrm{N}(2)^{3}-\mathrm{Fe}(2)-\mathrm{N}(2)^{4}$ & $91.31(13)$ \\
\hline$F(3)-F e(1)-F(2)$ & $88.2(3)$ & $F(1)^{1}-F e(2)-F(1)$ & 180 \\
\hline$F(4)-F e(1)-F(2)$ & $180.00(1)$ & $\mathrm{F}(1)^{1}-\mathrm{Fe}(2)-\mathrm{N}(2)^{2}$ & $88.19(8)$ \\
\hline$F(6)-F e(1)-F(2)$ & $133.8(11)$ & $\mathrm{N}(2)^{4}-\mathrm{Fe}(2)-\mathrm{N}(2)^{5}$ & 180 \\
\hline$F(4)-F e(1)-F(3)$ & $91.8(3)$ & & \\
\hline
\end{tabular}

Table 6: Main bonds angles $\left(^{\circ}\right)$ for $[\mathrm{Hdma}] \cdot\left(\mathrm{Fe} 2+\mathrm{Fe} 3+\mathrm{F} 6(\mathrm{Hamtaz}){ }_{2}\right)$ material Symmetry codes: (1) $-x+1 / 2,-y+1 / 2,-z+1 / 2 ;$ (2) $x, y+1 / 2,-z+1$; (3) $-x+1 / 2,-y$, $z-1 / 2 ;(4) x,-y,-z+1 ;(5)-x+1 / 2, y+1 / 2, z-1 / 2 ;(6) x,-y+1 / 2, z$.

the exponents gives the overall dimensionality of the structure. The results of thermal analysis suggest that the decomposition take place in two steps and at high temperature the $\mathrm{Fe}_{2} \mathrm{O}_{3}$ hematite compounds is product.

\section{Acknowledgements}


Citation: Smida M, Lhoste J, Dammak M, Ribaud AH, Leblan M, et al. (2017) Synthesis, Crystal Structure and Thermal Behaviour of a New Threedimensional Hybrid Fluoride Framework with Mixed Valence: $\left(\mathrm{Fe}^{2+} / \mathrm{Fe}^{3+}\right)$. Chem Sci J 8: 161. doi: 10.4172/2150-3494.1000161

Page 5 of 5

The authors would like to thank AM Mercier for chemical preparation and C. Galven for TGA experiments.

\section{References}

1. Liu JQ, Wang YY, Zhang YN, Liu P, Shi QZ (2009) Eur J Inorg Chem 1: 147.

2. Su Z, Fan J, Okamura T, Sun YW, Ueyama N (2010) Cryst Growth Des 10: 3515.

3. Patrick J, Clément S (1996) Hybrid organic-inorganic materials: a land of multidisciplinarity. J Mater Chem 4: 1-5.

4. Goforth MA, Su CY, Hipp R, Macquart RB, Smith MD, et al. (2005) J Solid State Chem 178: 2511

5. Collins DJ, Zhou HC (2007) J Mater Chem 17: 3154.

6. Zou RQ, Sakurai H, Xu Q (2006) Preparation, adsorption properties, and catalytic activity of 3D porous metal-organic frameworks composed of cubic building blocks and alkali-metal ions. Angew Chem Int Ed 45: 2542- 2546.

7. Halper SR, Do L, Stork JR, Cohen SM (2006) Topological control in heterometallic metal-organic frameworks by anion templating and metalloligand design. J Am Chem Soc 128: 15255-15268.

8. Ye Q, Fu DW, Tian H, Xiong RG, Chan PWH, et al. (2008) Huang Inorg Chem 47: 772 .

9. Zhang JP, Lin YY, Huang XC, Chen XM (2005) J Am Chem Soc 127: 25495.

10. Horcajada P, Gref R, Baati T, Allan PK, Maurin G, et al. (2012) Metal-organic frameworks in biomedicine. Chem Rev 112: 1232-1268.

11. Férey G, Millange F, Morcrette M, Serre C, Doublet M, et al. (2007) Angew Chem 46: 3259-3261.

12. Adil K, Ben AA, Leblanc M, Maisonneuve V (2006) Solid State Sci 8: 698.

13. Adil K, Saada MA, Ben AA, Body M, Dang MT, et al. (2007) Ternary and tetrahedral symmetry in hybrid fluorides, fluoride carbonates and carbonates. J Fluorine Chem 11: 1709-1714.

14. Kiriasis L, Mattes R, Anorg Z (1991) Allg Chem 593: 90.

15. Bentrup U, Massa W, Naturforsch Z (1991) Chem Sci 46: 395
16. Silva MR, Matos BA, Costa BFO, Paixao JA, Alte VL, et al. (2000) J Fluorine Chem 106: 77-82.

17. Ali AB, Trang DM, Greneche JM, Hémon-Ribaud A, Leblanc M, et al. (2007) J Solid State Chem 180: 1911.

18. Ben AA, Greneche JM, Leblanc M, Maisonneuve V (2009) [H 3 tren] 3+ templated iron fluorides; synthesis, crystal structures and Mössbauer studies. Solid State Sci 11: 1631-1638.

19. Malinovskii ST, Corpceanu EB, Bourosh PN, Rija AP, Bologa OA, et al. (2008) Synthesis and structure of cobalt(III) dimethylglyoximate with [FeF5(H2O)]2anion. Russ J Coord Chem 34: 422-426.

20. Fourquet JL, Plet F, Calage Y, De PR (1987) J Solid State Chem 69: 76

21. Smida M, Dammak M, Garcia-Granda S (2017) A new hybrid iron fluoride bipyridine with mixed valence: $\mathrm{Fe}_{2} \mathrm{~F}_{5}(2,2 \text { '-bipyridine })_{2} \mathrm{H}_{2} \mathrm{O}$. Indian Journal of Chemistry 55: 810-815.

22. Smida M, Lhoste J, Pimenta V, Hémon-Ribaud A, Jouffret L, et al. (2013) New series of hybrid fluoroferrates synthesized with triazoles: various dimensionalities and Mössbauer studies. Dalton Trans 42: 15748-15755.

23. Czakis-Sulikowska D, Katuzna-Czapliñska J (2000) J Ther Ana Calor 62: 821

24. GM Sheldrick (1986) SHELXS-86, Program for the Refinement of Crystal Structures. Univ of Gottingen, Germany.

25. Sheldrick GM (1997) SHELXL-97, Program for the Solution of Crystal Structure, GÖttingen University, Germany.

26. Farrugia LJ (1999) WinGX suite for small-molecule single-crystal crystallography. J Appl Cryst 32: 837-838.

27. Brandenburg K, Berndt M (1999) DIAMOND Version 2.1.b, Crystal impact Bonn GR, German.

28. Ferey G, Millange F, Morcrette M, Serre C, Doublet M, et al. (2007) MixedValence Li/Fe-Based Metal-Organic Frameworks with BothReversible Redox and Sorption Properties. Angew Chem Int Ed 46: 3259-3263.

29. Cadiau A, Le BA, Hemon-Ribaud A, Leblanc M, Body M, et al. (2010) Evolution of Guanazolium Fluoroaluminates within the Composition-Space Diagram and with the Temperature. Cryst Growth Des 10: 5159-5168.

30. Cheetham AK, Rao CNR, Feller RK (2006) Structural diversity and chemical trends in hybrid inorganic-organic framework materials. Chem Commun 46 4780-4795. 